\title{
Leadership Traits For Budding Entrepreneurs
}

\author{
Dr Deepa Katiyal \\ Associate Professor \\ Shri Vaishnav Institute of Management, Indore.
}

\begin{abstract}
It is relatively easy to identify and recognize good leaders, while it is difficult to define what constitutes good leadership"This paper is based on recognizing the traits of leadership to become an Entrepreneur. Generally we are reading and discussing the life of foreign Entrepreneurs like Bill Gate, Steve Jobs but in this paper, we try to enlighten our students ,how to become a successful leader in Indian culture and environment. From inside the minds of top CEOs of India, here are invaluable lessons on the most significant aspects of leadership. The most successful leaders have given their own traits of leadership which they themselves have discovered in their own course of life. They have not tried to copy or practice those traits of leadership which are stereotyped. In this paper, secondary data available on all the Seven CEOs are reviewed and then summarized. First of all, the traits given importance by them are analyzed and enlisted, and then a comparative report is prepared in the form of conclusion in which a summary of all important traits required for becoming a good leader are recognized and suggested.
\end{abstract}

Key words: Entrepreneur, Leaders, leadership, traits.

\section{INTRODUCTION}

Seven outstanding leaders have spelt out their perceptions of what is good leadership, and following that you can become not only a good leader but also a successful entrepreneur. The professional experience of each one of them is lesson in leadership. Iconic business leaders of their leadership beliefs and experiences are an account of leadership experiences in the real world. They are the survival of the fittest.Traditionally leadership has been considered to be either heritance for those born in powerful families but in the past decades there is tremendous change in the way people think about leadership. Now not only personal characteristics but task and organizational characteristics are equally important. Suitability and adaptability are more important than personal deal. We can also say that this paper support, Leaders are not born but made.

Kumar Mangalam Birla was born into entrepreneurial family and succeeded to the corporate throne in due course of time. He is the Chairman, Aditya Birla Group Education. Chartered accountant; MBA from London Business School. He took over the reins of the Aditya Birla Group after his father Aditya Vikram Birla passed away in 1995.

Adi Burjorji Godrej is an Indian industrialist and businessman, head of the Godrej Family, and chairman of the Godrej Group. As of 2015 , he is the 405th richest person in the world with a net worth of US\$4.0 billion. He is MBA from the MIT Sloan School of Management. After his return to India, he joined the family business. He modernized the management structure and implemented many new mantra to improve the functioning of his organization. Over the years, he has been a recipient of several awards and recognitions.

N.R. Narayanamurthy is an iconic institution-builder. He established Infosys in 1981. Before starting Infosys, Murthy worked with Indian Institute of Management Ahmadabad as chief systems programmer and Patni Computer Systems in Pune (Maharashtra) .Murthy has been listed among the 12 greatest entrepreneurs of our time by Fortune magazine. He has been described as Father of Indian IT sector by Time magazine due to his contribution to outsourcing in India. Murthy has also been honored with the Padma Vibhushan and Padma Shri Awards.

Chanda Kochhar has emerged as an exemplary career woman, working her way up in ICICI, starting as a management trainee and rising up to the apex level. After graduating in 1982, she studied cost accountancy, and later acquired a master's degree in management studies from Jamnalal Bajaj Institute of Management Studies, Mumbai. She received the Wockhardt Gold Medal for Excellence in Management Studies as well as the J. N. Bose Gold Medal in Cost Accountancy.

Deepak Parekh is identified with the creation and growth of HDFC, which he did step by step. He is the Chairman, Housing Development Finance Corporate Ltd (HDFC). For not only has Parekh steered the company 
into one of India's top housing companies, it has brought to fruition the dream of lakhs of middle-class Indians of owning houses.

Ratan Naval Tata was born on 28 December 1937. He is an Indian businessman, investor, philanthropist and former chairman of Tata Sons. He was the chairman of Tata Group, a Mumbai-based global business conglomerate from 1991 till 2012 and again from 2 October 2016 for interim term, and continues to head its charitable trusts.He is the recipient of two of the highest civilian awards of India-Padma Vibhushan (2008) and Padma Bhushan (2000) .He is an alumnus of the prestigious Cathedral and John Connon School, Bishop Cotton Shimla,Cornell University and Harvard Business School.Mukesh Ambani is an able administrator who steered Reliance to incredible height in the last two decades after his father Dhirubhai Ambani's death. He and his brother Anil inherited their father's business and then started diversifying. Mukesh Ambani, now the Chairman and Managing Director of Reliance Industries Limited, India's largest private sector company, has set an excellent example of being a successful leader \& carrying forward the legacy of the Ambani realm. His leadership abilities were recognized by eminent bodies in the industry by felicitations like Economic Times Business Leader 2006 \& CNBC-TV18 India Business Leader Awards 2007.

\section{LITERATURE REVIEW}

J.S. Saini and B.S. Rathore (2001) in their book titled Entrepreneurship: Theory and Practice, deal with entrepreneurial philosophy, where the success of entrepreneurs based on leadership traits has been discussed. According to the authors, success of an entrepreneur depends on the entrepreneur's willingness to hold responsibility for his own work. Though the risk of failure is always present, he takes risks by assuming responsibility for his actions. Learning from past experiences will help channel his actions to obtain better results and persistent efforts will yield success for sure. Bholanath Dutta (2009) in his book, Entrepreneurship Management: Texts \& Cases, deals in detail on the factors and traits influencing entrepreneurship.The author has elucidated the characteristics of a successful entrepreneur at length. According to him, there are many critical factors contributing success such as skills, innovative mind, decision making, creative, plan making, dynamic, self confidence and ambitiousness, risk bearing, and adventurous mind. S.S.Khanka (2009) in his book Entrepreneurship Development illustrates the personal characteristics of successful entrepreneurs as hard work, desire for high achievement, high optimism, independence, foresight, good organizing capacity, and innovativeness. According to the author, success of a small enterprise is, to a great extent, attributed to the success of the entrepreneur himself. David H. Holt (2000) in his book Entrepreneurship: New Venture Creation has dealt in detail about the success factors for entrepreneurs. Holt says at the top of the success factor list is the "Entrepreneurial Team" comprising of partners, associates or extensive network of advisors Holt is emphasizing the point that success is closely related to a solid knowledge base and substantial experience in related field of operations. Moreover, they will also have well developed social and business relationships and therefore, have a strong foundation for building a team or support network. Mary Kay Copeland (2010) in her article, Strategies of a Successful Entrepreneur: Nature or Nurture, in MBA Review, has deliberated on the characteristics of a successful entrepreneur. According to the author, the behaviours and personality characteristics that leading researchers have found in effective and successful entrepreneurs are - self confidence, risk taking capacity, discerning power, inquisitiveness, tolerance of ambiguity and uncertainty, creativeness, resourcefulness, affinity for autonomy and control, opportunism, optimism, action-orientedness, intuitiveness, persuasion, adaptation, resilience.

\section{OBJECTIVE OF THE STUDY}

1)To study the leadership traits of all the seven renowned leaders.

2)To study and compare the leadership traits of all the leaders taken in the study.

3)To conclude the best and necessary leadership traits which can be used as benchmark for the budding entrepreneurs and also for successful leaders.

\section{RESEARCH METHODOLOGY}

The study is based on all secondary data available. Intensive study of all the books, articles, journals, online material available on all the seven leaders is done. After the analysis the leadership traits of all the leaders are summarized and a comparative report is prepared for conclusion.

\section{LEADERSHIP TRAITS OF SEVEN CEO'S LEADERS KUMAR MANGALAM BIRLA}

"The job of the leader is to keep the status quo, the established way of doing things, under constant challenge" K.M.Birla has described some turning points of his life which changed his course of life and helped him in becoming a good leader. He gives lot of importance to team and team formation. Individuals are stars but team of stars lead to the brilliance of galaxy. Change is the key to success. A leader should always welcome 
change. Leadership is all about plugging into the mind and heart of people. Employees should dream big with all passion and the fire within you. It is very important to connect performance with rewards, who are doing well to be told that they are doing well.

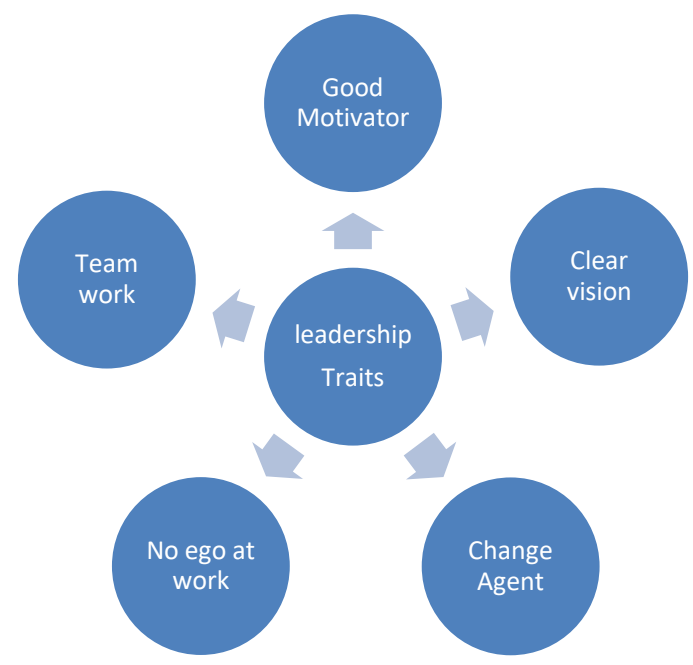

Fig. I : Leadership Traits Model by K.M.Birla

\section{ADI GODREJ}

"Leadership is about doing the tough things which need to be done and no one else wants to do, not just the popular ones. It is about telling the truth about how things are, not what people want to hear."Adi Godrej says, "My mother was my first and best mentor." He is a firm believer in teamwork: "It takes two to tango." As a management student, one of the key things he had learnt was the importance of building teams and retaining people, an idea that he imbibed earlier in his career and it stayed with him all through. "I learnt the power of team work". He believes in the power of knowledge. Adi Godrej is well known in the business circles to be a man who knew every grain of his trade, and every price of his raw materials .he would know every nickel and dime of trade. Another paradigm close to his heart is that "The key lies in thinking about the future backwards, not the present forward. He has given importance to integrity in values, beliefs, thoughts, ideas. Failure leads to learning, the biggest challenge you face leads to confidence. Have clear vision milestones, what way you like to contribute leads to opportunities. Dream big, don't negotiate with your dreams. Work hard for team to create collective ideas.

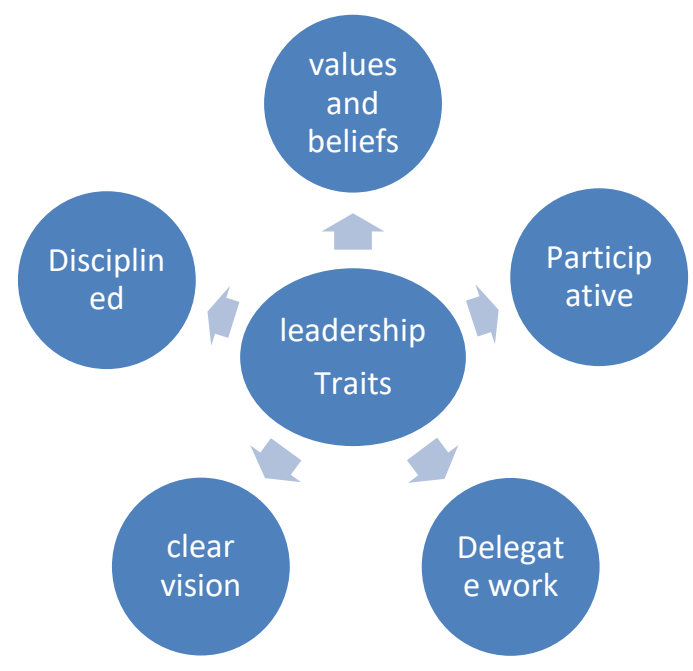

Fig. II: Leadership traits Model by Adi Godrej

N. B. NARAYAN MURTHY

"Take your work seriously, but do not take yourself too seriously" 
He has shared his view about leadership. He has enlisted some qualities of leaders having powerful vision, commitment to values, build trust, demonstrate courage, open and fair. Create an inducive environment, practice good corporate governance. Lay down clear operating philosophy. Always raising the confidence of followers. Always making employees understand that tough times are part of life and that they will come out better at the end of it. For a successful leader, a constant learning process is very important. When due to lack of knowledge, a leader cannot provide solution to the team, he loses respect in their eyes. And sometimes he has to pay a heavy price for that. Leadership and learning are indispensable. Narayan Murthy Knows that The success depends on placing right people at right task. And hence he developed an ability to identify the strengths of his team member and utilize to them optimally.

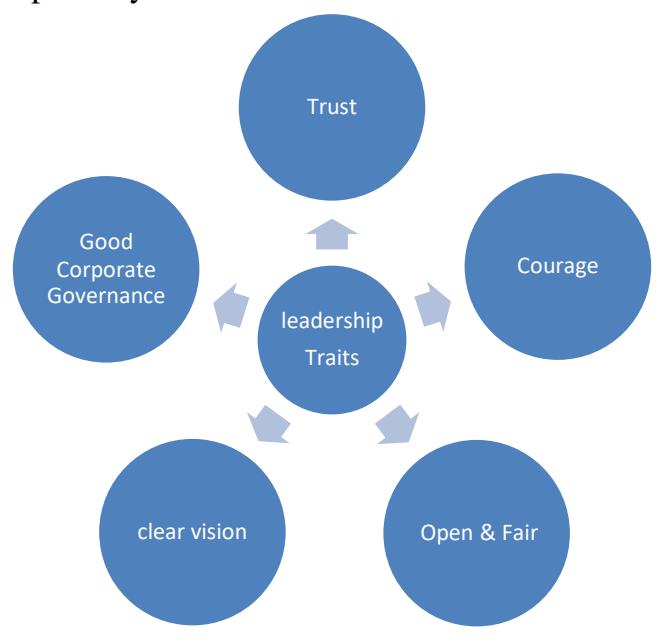

Fig. III : Leadership traits Model by N.B. Narayanmurthy

\section{CHANDA KOCHCHAR}

"Leadership is best learnt experientially...by taking on challenges and seeking out opportunities." Coping with a more volatile environment is a challenge common to many leaders. They constantly survey the horizon to anticipate that next big change. Scenario planning has always been important, but these days change can come so much more quickly. So we are always asking "what if." So she trusts on the team work. Brainstorming sessions are important for team formation. Leaders must have one eye on the broad trends - what is happening in the world? What is the next volatile thing that can hit you? - and at the same time have a very clear view of day-to-day operations. I think one of the big challenges for leaders today is that windows for effective execution have gotten smaller. It is importance to be a good listener, but something more than that is required. You have to not just listen but absorb - to take in everything like a sponge - so that when you do make that final call, it's not just based on whims and fancies. A leader should be a good communicator, once you've made that decision, it's very very important for leaders to make sure the rest of the team understands your vision and the reasoning behind it. Your communication with your team members has to be such that they actually understand the logic and the benefits of your choice and therefore are with you in execution. Every leader has certain great qualities, and every leader has some things that need to be worked on. He should be a good learner.

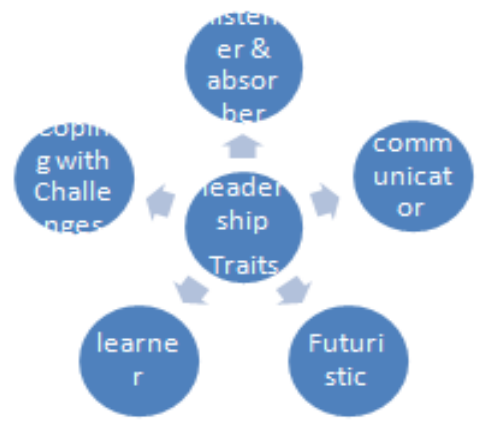

Fig. IV : Leadership traits Model by Chanda Kochchar 


\section{DEEPAK PAREEKH}

"Leadership is all about moving ahead with two basic instruments - the compass and the clock. One which confirms the direction you are moving in and the other tells you how fast you will get there." Management is efficiency in climbing the ladder of success, leadership determines whether the ladder is on the right wall. The most important quality a leader must have is vision. Unless a leader has in sight the goal, is focused on it and then paves the way to reach it, little can be achieved not matter how much hard work is put into the attempt. However, his passion is not limited to making businesses grow. He should have great values and principles. Intuition for future strategies is must A leader should be great believer in youth and new leadership styles. The leader should holds values such as integrity, transparency and trust in the highest regard - values that are questioned time and again, but have, in the end, worked best in any sphere of life. A capable leader should be showing the way.

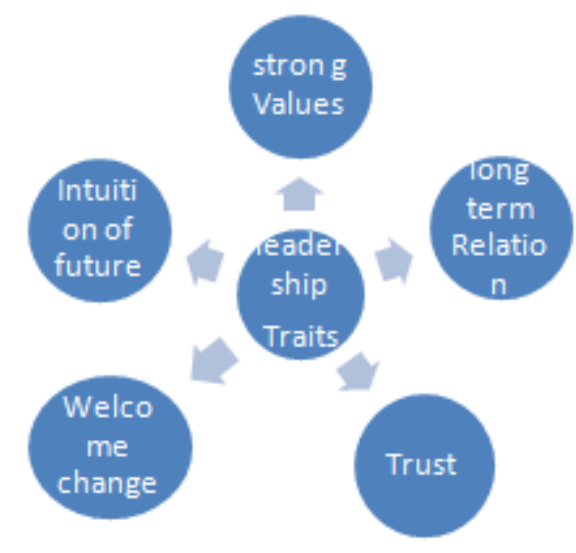

Fig. V : Leadership traits Model by Deepak Pareekh

\section{RATAN TATA}

"Leader has bigger and high purpose role in the organization that expresses responsiveness to community."While some organizations do create the higher purpose, they do not operationalize that. In the absence of translating the higher purpose into actions, these statements become static and meaningless, limited to websites and decorating boardrooms. It is the role of the leader imbibe their higher to experience more meaning in their life and fulfillment. Leader should use creative tendencies than reactive tendencies to get results. Some people achieve results using reactive competencies and tendencies like controlling, manipulating, pleasing and complying. While some others would achieve similar or better results using creative tendencies like relating, self awareness, purposeful actions, and authenticity. A Leader should have strong character, commitment, competence and courage.

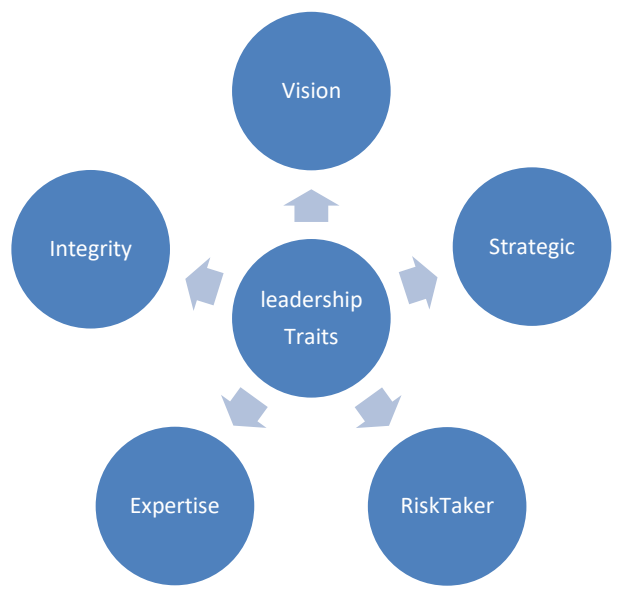

Fig. VI : Leadership traits Model by Ratan Tata 


\section{$\mathbf{X}$.}

\section{MUKESH AMBANI}

"A true leader is who loves challenging situations."

A leader should be revolutionary. All the old habits which are not applicable now should be discarded immediately. There was no substance in keeping the power in a few people's hands and so the authority should spread over a network of people who should be given specific responsibilities. The vision of Mukesh, set a world record. He believes in strong vision. He should see far into the future and pinpoint the businesses that would change the face of his company profile. Use and introduction of new technology can lead to heights. Continuous Training and Development programs should be introduced by the leader for the team for upgrading of new technologies in the global world. A true leader always believes in investing the company's capital on good talent. It was his wish that opportunities in India should not be limited to the few so that every citizen is empowered to access new generation technology \& skills. He envisaged a new India on the horizon - new visionary, courageous and convincing models that are needed to progress Indian society. He always challenged the possibility to translate this vision into reality.

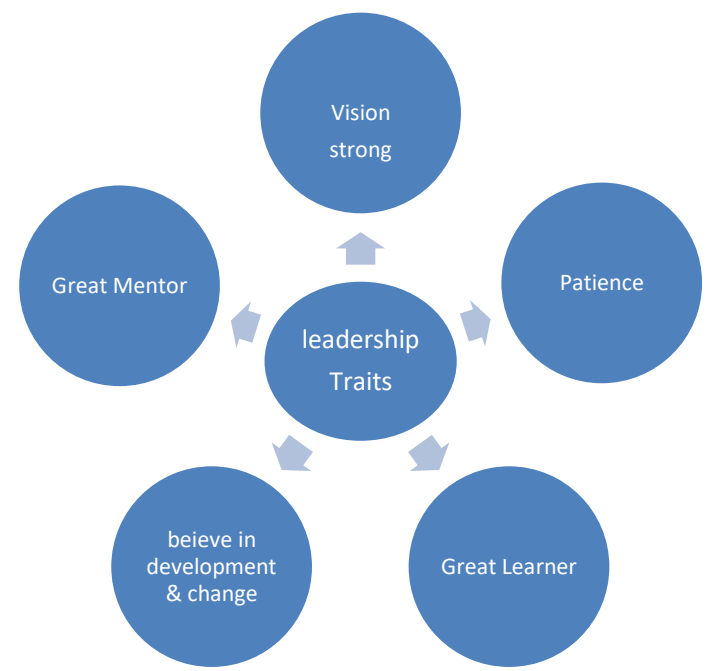

Fig. VII : Leadership traits Model by Mukesh Ambhani

XI. FINDINGS AND INTERPRETATION

All the entrepreneurs and leaders included in the study have different concepts and experience regarding Leadership. A comparative table is formulated for understanding and interpreting the results.

\begin{tabular}{|l|l|l|l|l|l|l|}
\hline $\mathbf{1 .}$ & K.M. BIRLA & $\begin{array}{l}\text { Good } \\
\text { Motivator }\end{array}$ & Team work & $\begin{array}{l}\text { No ego } \\
\text { problem }\end{array}$ & $\begin{array}{l}\text { Calm and } \\
\text { composed }\end{array}$ & $\begin{array}{l}\text { Great } \\
\text { Vision }\end{array}$ \\
\hline $\mathbf{2 .}$ & ADI GODREJ & Values & Disciplined & $\begin{array}{l}\text { Delegate } \\
\text { work }\end{array}$ & Participative & $\begin{array}{l}\text { Clear } \\
\text { Vision }\end{array}$ \\
\hline $\mathbf{3 .}$ & $\begin{array}{l}\text { N.B. } \\
\text { NARAYANMURTHY }\end{array}$ & Trust & Courage & $\begin{array}{l}\text { Open } \\
\text { and Fair }\end{array}$ & $\begin{array}{l}\text { Good } \\
\text { corporate } \\
\text { Governance }\end{array}$ & $\begin{array}{l}\text { Clear } \\
\text { Vision }\end{array}$ \\
\hline $\mathbf{4}$ & $\begin{array}{l}\text { CHANDA } \\
\text { KOCHCHAR }\end{array}$ & $\begin{array}{l}\text { Good } \\
\text { Listener }\end{array}$ & $\begin{array}{l}\text { Good } \\
\text { Learner }\end{array}$ & $\begin{array}{l}\text { Coping } \\
\text { with } \\
\text { challenge }\end{array}$ & Communicator & Futuristic \\
\hline $\mathbf{5 .}$ & DEEPAK PAREEKH & $\begin{array}{l}\text { Long term } \\
\text { Relationship }\end{array}$ & $\begin{array}{l}\text { Strong } \\
\text { Values }\end{array}$ & $\begin{array}{l}\text { Welcome } \\
\text { Change }\end{array}$ & Trust & $\begin{array}{l}\text { Intuitive } \\
\text { of future }\end{array}$ \\
\hline $\mathbf{6 .}$ & RATAN TATA & Strategic & Risk taker & Expertise & Integrity & Visionary \\
\hline $\mathbf{7 .}$ & MUKESH AMBANI & Patience & $\begin{array}{l}\text { Great } \\
\text { Learner }\end{array}$ & $\begin{array}{l}\text { Good } \\
\text { Mentor }\end{array}$ & $\begin{array}{l}\text { Believe in T } \\
\text { and D }\end{array}$ & $\begin{array}{l}\text { Vision } \\
\text { with } \\
\text { Value }\end{array}$ \\
\hline
\end{tabular}

Table 1: Comparative description of Leaders 
Good leaders develop through a never ending process of selfstudy, education, training and Develpment. Leaders hip is a process whereby an individual influences a group of individuals to achieve a common goal .A leader must have an honest understanding of who he or she is and what he or she can do. To be successful a leader has to convince his follower to give their best so that they achieve a common goal. The leader has to be practical andrealistic, yet must talk the language of the visionary and the idealist. One of the most important quality a leader must have is vision.

On the starting of the career two things have to be on priority: Great Vision of future and to have good team. Dream big and have defined goals based on strong vision. But it should be realistic and feasible. Give importance to team work and believe in shared responsibilities and authorities. Delegate work and be participative. If you want to reach heights then have strong values, beliefs, no ego problems, be calm and composed with lot of patience. Motivate your team for hard work and then have trust on them. Long term relationship will help in good corporate governance.Risk taking and accepting the challenges and changes are the key words which should always be remembered. Continuous learning leads to higher expertise and strategic Management, so, have an open communication system, good listener, organize Training and Development Programmes for the employees and believe in mentorship.

\section{MODEL OF LEADERSHIP FOR BUDDING ENTREPRENEURS}

\section{- Personal Traits}

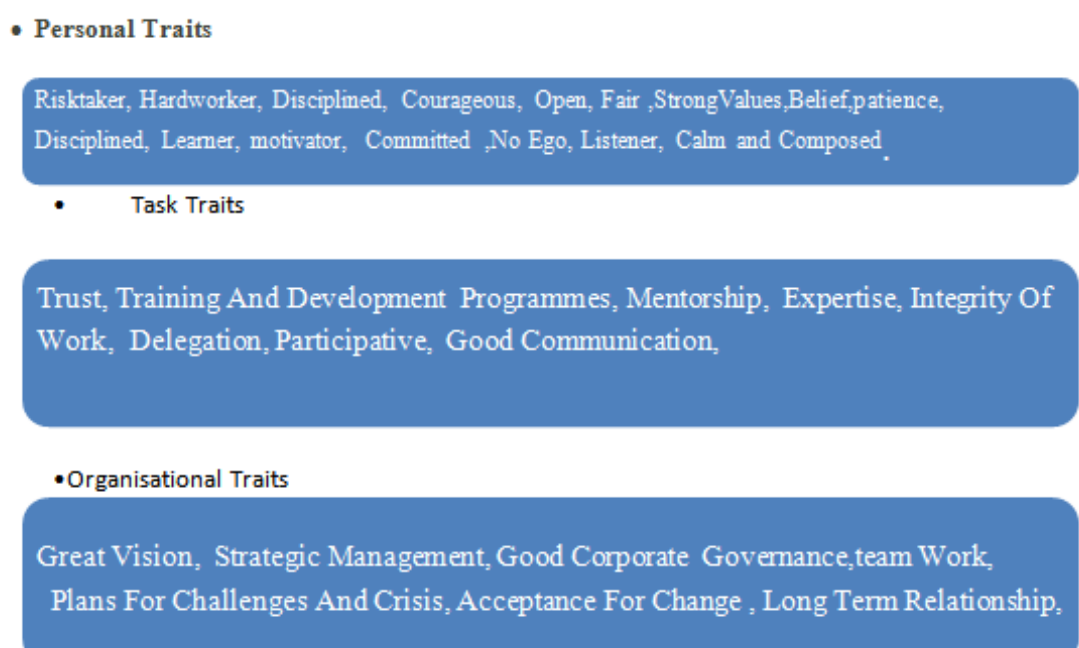

\section{CONCLUSION}

Their stories of success have proved that leadership is an art which increases with experience. It can be learned but not adopted, rejects "one-size-fits-all" concept also. With contributions from celebrated business leaders like Kumar Mangalam Birla, Adi Godrej, Chanda Kochhar, N.R. Narayana Murthy, Deepak Parekh, Ratan Tata and Mukesh Ambani, all the budding leaders and entrepreneurs should appreciate the journey of these leaders from being undistinguished individuals to becoming celebrated corporate luminaries; to draw inspiration and learn from their struggles and achievements. If we have the desire and will power we can become an effective leader. They can become role models for all the new leaders, entrepreneurs and managers.

\section{REFERENCES}

[1] Bass, B.M., Avolio, B.J. (1995) Multifactor Leadership Questionnaire for Research. Mind Garden: Palo Alto, CA.

[2] Bholanath Dutta, Entrepreneurship Management: Text and Cases, Excel Books, New Delhi, 2009.

[3] Conger, J.A. (1998), Qualitative research as the cornerstone methodology for understanding leadership. Leadership Quarterly, 9 (1), 107-122.

[4] David H. Holt, Entrepreneurship: New Venture Creation, Prentice - Hall of India Private Ltd., New Delhi.2000.

[5] Judge, T.A., and Bono, J.E. (2000), Five-factor Model of Personality and Transformational Leadership. Journal of Applied Psychology, 85(5), 751-765. Kakar, S., Kakar, S., Kets de Vries, M.F.R.

[6] Khanka S.S., Entrepreneurship Development, S. Chand\& Co. Ltd., New Delhi.2009. 
[7] Mary Kay Copeland,(2010) Strategies for developing Entrepreneurship: Nature or Nurture? MBA Review - Special edition on Entrepreneurial Skills,Hyderabad.

[8] Saini, J.S(1993)., Effectiveness of Entrepreneurship Development Programmes in Northern India, Doctoral Research, Department of Business Management, Punjabi University, Patiala. 